\title{
Renaissance Exempla of Schizophrenia: \\ The Cure by Charity in Luther and Cervantes*
}

WINFRIED SCHLEINER

It is a commonplace that literature and life intersect in many places. Even without adopting philosophic concepts (the Kantian categories, say, or Cassirer's symbolic forms) as tools for probing facts in various realms of experience, a literary scholar may point to the derivation of many narrative or dramatic episodes and plots from actual cases: moral, judicial, and medical. But derivation certainly does not imply primacy of importance of the source, i.e., if we study the interplay of disciplines in actual casus, reciprocal fertilization between disciplines is more apparent than mere debt. Indeed, if we pursue the Renaissance thinking about one kind of medical case, namely what we would now call schizophrenia, and particularly the delusions associated with it, Francis Bacon seems to have been right for that period when he said pointedly that "Medicine is a Science, which hath been ... more professed, than laboured, and yet more laboured, than advanced." While some cases of psychoses and some minimal classification of them have their firm place in disquisitions on "melancholy" from the earliest medical authors onwards, it seems that such cases needed sympathetic penetration by thinkers outside the medical academy for the full extent of suffering in them to be realized-perhaps an analogue to recent impulses the treatment of psychotics has received from a movement sometimes called "anti-psychiatry."2

In our period the troubled mind will derive not only insight but sustenance from the sympathetic account of schizophrenia in a book like R. D. Laing's The Divided Self. Describing the exaggerated desire for privacy and the acute sense of vulnerability in these patients, Laing points out that their sense of being exposed and vulnerable is carried to such an extreme that one of them "may say that he is made of glass, of such transparency and fragility that a look directed at him splinters him to bits and penetrates straight through him,"3 or that a man who says he is dead "means that he is

* The research for this article was supported by a grant from the Herzog August Bibliothek, Wolfenbüttel, Germany. Ruth El Saffar, Alan S. Trueblood, and Michael A. Hirsch, M.D. read earlier versions of it and made valuable suggestions. 


\section{8 / Renaissance and Reformation}

'really' and quite 'literally' dead, not merely symbolically or 'in a sense' or 'as it were'."4 According to one of Laing's patients, the fear of being hurt can be pitched to such a degree that the person "really wants to be dead and hidden in a place where nothing can touch him and drag him back" (p. 180).

While there is a strong ancient and Renaissance tradition linking madness and genius in the notion of genial or heroic melancholy (powerfully presented by Ficino, Agrippa of Nettesheym, and Melanchthon), medical writers of the period rarely show any sympathy for such delusive conditions as those described by R. D. Laing. Although cases like that of someone believing himself dead or thinking himself a clay vase or a glass jug or a helpless bird are often mentioned as special cases of melancholy (some go back to Hippocrates and Galen), one must look to theologians and writers of fiction to find sympathetic treatments of the condition. It is not in Marcello Donati, Hercules of Sassonia, Andre du Laurens, Juan Huarte, and perhaps not even in the highly courageous and innovative Johann Wierus (Weyer) or the perceptive Thomas Fienus (Feyens), whose De viribus imaginationis elicited Robert Burton's highest praise, but in the ostensible anti-melancholics Luther and Cervantes that the condition of such psychotics and the ambiguity of their cure are most clearly presented.

\section{The Laughable Psychotic}

As I noted above, cases of persons thinking themselves other than they were (a clay jar, a cock with flapping wings) are included in ancient discussions of melancholy such as Galen's De affectis (Bk. 3 ), ${ }^{5}$ but there is no question that Renaissance doctors delighted in them, expanded them by introducing local detail, and added new ones for their comic interest, often dated and localized, to the popular case books. Thus Renaissance handbooks of medical and related knowledge are filled with cases of deluded people who frequently try to impose their vision upon their neighbors. Often the authors or compilers do not even try to conceal their amusement: "Quite ridiculous is also the case of the person who went to Murano to throw himself into a furnace wanting to have himself turned into a salad bowl.""6

Without belabouring this point with a variety of cases from the curiosity shop of Renaissance medicine, let me add only one of a voluntary retentive that almost invariably elicited amusement. The French physician André du Laurens writes

The pleasantest dotage that ever I read, was of one Sienois a Gentleman, who had resolved with himselfe not to pisse, but to dye rather, and that because he imagined, that when he first pissed, all his towne would be drowned. The 


\begin{abstract}
Phisitions shewing him, that all his bodie, and ten thousand more such as his, were not able to containe so much as might drowne the least house in the towne, could not change his minde from this foolish imagination. In the end they seeing his obstinacie, and in what danger he put his life, found out a pleasant invention. They caused the next house to be set on fire, $\&$ all the bells in the town to ring, they perswaded diverse servants to crie, to the fire, to the fire, and therewithall send of those of the best account in the town, to crave helpe, and shew the Gentleman that there is but one way to save the towne, and that it was, that he should pisse quickelie and quench the fire. Then this sillie melancholike man which abstained from pissing for feare of loosing his towne, taking it for graunted, that it was now in great hazard, pissed and emptied his bladder of all that was in it, and was himselfe by that means preserved.?
\end{abstract}

The earliest instance I have seen of this story is in Marcello Donati, but it may well have already been part of the bedrock of medical commonplace before him. While Burton tells only half of the case, the Englishman Thomas Walkington presents this melancholic as "of all conceited famous fooles ... most worthy to be canoniz'd in the chronicles of our memory," and almost a century later the compiler Laurentius Beyerlinck identifies this case as the "most ridiculous" of all stories of melancholics. ${ }^{8}$. It is quite possible that Swift was thinking of the man of Siena when he had Gulliver so effectively extinguish the fire in the Queen's apartments.

The "humour" in the last case does not derive merely from its violating some sexual or scatological taboo (though certainly breach of decorum is a vehicle of Swift's satire); this element is not present in the other cases that are called by Renaissance authors "ridiculous". Not breach of decorum but psychotic delusion is common to them all. Speaking of "melancholike persons, and mad men [who] imagine many things which in verie deed are not," Ludwig Lavater says "Those which dwell with suche kinde of men, when they here them tell such absurd tales, such strange things, and such marvellous visions, albeit they pittie their unfortunate estate, yet can they not many times containe themselves from laughing."9 Although Lavater refers to the pity of the patients' keepers, this reference actually amplifies the ridicule evoked by the psychotic delusions: the sense of the ridiculous overcomes pity. Of course the pain and inhumanity resulting from unsympathetic attitudes towards psychotics have mostly gone unrecorded. A striking exception is the case of a person whose death is reported as an instance of medical misjudgment (or we might say 'malpractice') or in answer to the question whether the imagination is so strong that it can kill. A man believes his body is no huge that he cannot pass through a door and therefore refuses to leave his room. When at the request of the physician several helpers carry the screaming patient through the doorway by force, he feels his body to have been shattered inside and falls so ill that he dies shortly afterwards. ${ }^{10}$ 


\section{The Erasmian Praise of Mental Distraction and}

\section{the (Pseudo-) Aristotelian Praise of Melancholy}

A related but significantly different Renaissance attitude towards psychotic delusion is what for want of a better term I will call the "Erasmian," an attitude perhaps more humanistic than humane, drawing some support from the ancients. In Praise of Folly, Erasmus' ambiguous speaker (Folly) describes a "pleasant mental distraction [that] relieves the heart from its anxieties" " and distinguishes it from destructive madness. While destructive madness is sent up from the underworld by the avenging Furies, this madness takes its origin from Folly, the imagined speaker, and according to her is "most desirable": "It occurs whenever a certain pleasant mental distraction relieves the heart from its anxieties and cares and at the same time soothes it with the balm of manifold pleasures." 12 Folly refers to one of Cicero's letters to Atticus (3.13) claiming that "Cicero wishes for this mental distraction as a great gift from the gods, because it would have deprived him of all awareness of the great evils around him," but two recent editors of Praise of Folly have corrently pointed out that Cicero does not say what Folly here attributes to him. ${ }^{13}$ Although Cicero may be the wrong informant, Folly effectively illustrates her view of this mental condition by reference to a case reported by Horace (Epist. 2.2.128-40):

Nor was there anything wrong with the judgment of the Greek who was so mad that he sat alone in the theatre for whole days on end, laughing, applauding, enjoying himself, because he thought that wonderful tragedies were being acted there, whereas nothing at all was being performed. But in the other duties of life he conducted himself very well: he was cheerful with his friends, agreeable with his wife; he could overlook the faults of his servants and not fly into a mad rage when he found a winejar had been secretly tapped. Through the efforts of his friends he took some medicine which cured him of his disease, but when he was completely himself again, he took issue with his friends in this fashion: "Damn it all!" he said, "you have killed me, my friends, not cured me, by thus wresting my enjoyment from me and forcibly depriving me of a most pleasant delusion."14

Erasmus is clearly not interested in the kind of medicine (which Horace reports to be hellebore). In the first version of the case I have seen, the medication is not even mentioned; Aristotle's exemplum makes the same general point (that the melancholic was happier in his delusion), but without the elaborate details Folly borrowed from Horace: "It is said that at Abydus a man who was mad went into the theatre and watched for many days, as if there were people acting, and showed his approval; and when he recovered from his madness, he said that he had enjoyed the best time of his life."15 In the Renaissance the case of this "melancholic" was well know. Ludwig Lavater recounts it in his work just mentioned together with an equally famous case of a melancholic called Thrasyllos; from Athenaeus 
to Burton, Thrasyllos is cited to show that a person can be happier in his melancholic delusion than after his cure:

\begin{abstract}
Atheneus [sic] lib. 12 writeth of one Tresilaus [in Athenaeus: Thrasyllos], whose braines were so distempered, that he verily supposed all the ships whiche aryved at Porte Piraeus, to be his owne: he would numbre them, he commaunded the Mariners to launch from shore, and when they returned after their voyage home againe, he as much rejoyced as if he had ben owner of all wherewith they were laden. The same man affirmed, that in al the time of his madness he lived a verie pleasant life, untill the Phisitian hadde cured him of his disease. ${ }^{16}$
\end{abstract}

As in Athenaeus, the cure is just a given, necessary to make the point of the story, but we do not learn how it was effected. ${ }^{17}$ In fact Lavater tells us even less about the patient's background, about whom Athenaeus relates that he was afflicted by madness "resulting from luxurious living."

Lavater's point in stringing these cases together is to illustrate a sense of amusement (resulting from the disturbed perception of reality) and to show the patient's preference for the deluded state. In Erasmus' Praise of Folly, the speaker takes the argument one step further, claiming that such states are generally desirable. To realize that Erasmus' speaker is Folly does not entirely discredit the view propounded; since the reader finds many of Folly's arguments (particularly in satiric passages) eminently reasonable, this realization merely helps to suspend the praise of deluded folly in a tantalizing and very Erasmian ambiguity.

Occasionally the view that a mentally deluded state is preferable to normalcy is supported by the (pseudo-) Aristotelian notion already mentioned, that melancholy is the precondition of all genius: "Why is it," Problem XXX, section 1 opens, "that all men who have become outstanding in philosophy, statesmanship, poetry or the arts are melancholic, and some to such an extent that they are infected by the diseases arising from black bile, as the story of Heracles among the heroes tells?"'18 Melancholics may philosophize in their illness - and only in their illness - or, although unlettered, may speak in perfect verses for days on end: the characteristic response elicited by such cases is not sympathy but wonder. Shakespeare accurately catches this mood when he has the Duke in As You Like It ask his men to lead him to the scene of melancholy Jaques's ravings: "Show me the place," the Duke says. "I love to cope [i.e., converse with] him in these sullen fits, / For then he's full of matter" ( $A Y L I$ II, i,66-68 [Riverside ed.]). The Duke's motive is not charity, but enjoyment of spectacle, i.e. an excitement he gets from Jaques' unusual association of ideas, perhaps satisfying his urge to catch a glimpse of the transcendent world.

We may study the blend of Erasmian and Aristotelian ideas in a case reported by the sixteenth-century doctor Juan Huarte de San Juan, a case 
that will later serve us as a basis for describing important transformations wrought by one of the greatest literary artists of the Renaissance. Huarte tells of the "notable speeches, uttered by a Page of one of the great ones of this realme, whilst he was made, who in his health was reported a youth of slender capacity." "19 Thus the pattern is similar to the Athenaean or Erasmian one, except that intellectual capacity attends illness and is considered more important than the patient's health. Huarte continues:

Falling into this infirmitie, he delivered such rare conceits, resemblances, and answers, to such as asked him, and devised so excellent manners of governing a kingdome (of which he imagined himselfe to be the soveraigne) that for great wonder people flocked to see him and heare him, and his very maister scarcely ever departed from his beds head, praying God that he might never be cured. Which afterwards plainly appeared, for being recovered, his Phisitian (who had healed him) came to take leave of his lord, with a mind to receive some good reward, if of nothing else, yet at least in good words; but he encountered this greeting: "I promise you maister doctor, that I was never more aggreeved at any ill successe, than to see this my page recovered, for it was not behooffull that he should change so [sic] wise folly, for an understanding so simple as is this, which in his health he enjoieth. Me-thinks that of one, who to fore was wise and well advised, you have made him a foole againe, which is the greatest miserie that may light upon any man." (Huarte, Examination of Mens Wits, p. 43)

Of course this is the sense of wonder a "melancholic's" stunning abilities usually evoke in Renaissance beholders, abilities that Huarte on the next page explains in terms of Problem XXX, as resulting from an unusual humoral mixture. First, however, he reports in Athenaean/Erasmian fashion the patient's own reaction to his cure. After politely thanking his doctor, the page says to him

I assure you on my faith, that in some sort, it displeaseth me to have bene cured. For whilest I rested in my folly, I led my life in the deepest discourses of the world, and imagined my selfe so great a lord, as there raigned no king on the earth, who was not my vassal, and were it a jeast or a lie, what imported that, whilest I conceived thereof so great a contentment, as if it had bene true? I rest now in far woorse case, finding my selfe in troth to be but a poore page, and to morrow I must begin againe to serve one, who whilst I was in mine infirmitie, I would have disdayned for my footman. (pp. 43-44)

Rather curiously this passage has the marginal comment "This page was not yet perfectly cured" representing accurately the annotation of the first edition (1575): "Este page aun no habia sanado del todo." ${ }^{20}$ The comment seems to indicate that its author, Huarte or his editor, was not entirely aware that the case of the page harking back to his pleasant delusions stood in the Athaenean/Erasmian tradition. As so often in cases deriving from this tradition, the medication or therapy that cured the page remains unmentioned. 


\section{Luther: Cure by Charity and Company (societas)}

If, then, a certain kind of psychotic case tended to attract medical ridicule and if the Erasmian notion of pleasurable delusion likewise did not lead to serious consideration of therapy, we may have to look elsewhere in the Renaissance for a glimpse of what has become so strikingly obvious in our times: that a knowledge of the patients' histories, empathy with their condition, and endeavors to understand their particular thought processes are important in the treatment of psychotics, whose suffering and pain are beginning to be fully recognized. A measure of the important of such thought now is the participation of psychiatrists and psychologists of the most diverse persuasions in community programs bringing together "primary consumers" and their friends and families.

Perhaps it is significant that I have found the most striking Renaissance intimation of such matters in a theologian and in a poet, who transmuted the medical commonplaces through their specific fears and predilections, and above all through an encompassing sympathy for the psychotic. While medical authors often had been content to map out diverse psychotic cases comparing the patient's psychotic to his sane state without suggesting any therapy or cure, the cases recounted in Luther's Tischreden (or Colloquia) are informed by a sense of caring for the patient and include the nature of the patient's cure. Indeed, it can be said that this sense of caring becomes a vehicle of therapy.

The first case is of a melancholic who refuses to eat and drink and hides in a cellar. He rebuffs any charitable helpers with the words "Don't you see that I am a corpse and have died? How can I eat?" Michel Foucault points out that a seventeenth-century medical author refers to a similar exemplum to show that the insane are capable of logical rigor, to such an extent in fact that they will starve to death for a syllogism..$^{21}$ Although in Luther's story the patient is not brought to revise his minor premise, which would mean sanity, at least he is induced to life-preserving illogic: after several days, when his life is in danger, his friends decide to set a table in the cellar; they bring in the most delicious dishes, select a monk for his embonpoint, and have him eat and drink loudly and demonstratively. By the feasting monk's example and company the melancholic is impelled to eat and drink: "I must drink with you and cannot help it, though I be dead a hundred times." 22

The second case (in some versions of the Colloquia not attributed to Luther but to his physician Lindemann) is of a melancholic who thought that he was a cock, with a red comb on his head, a long beak, and a crowing voice - surely since Galen one of the most hallowed medical topoi. But while Galen does not suggest a cure, this melancholicus is joined by an inventive person who simulates the gait and voice of a cock. After living with the patient in this manner for several days, he says "I am not a cock 
any more, but a human being; and you have returned to being human, too." And the speaker concludes with something like a moral, which would have been a fitting close for the previous case as well: "And by that company he cured him" (Et illa societate illum persuasit). ${ }^{23}$

The third case told by Luther is perhaps even more interesting because it resonates with echoes of the major theological divisions of the Reformation. It concerns a iustitiarius, or as the German text says more expressively, a Werkheiliger. Since the case of this voluntary retentive is at the same time a minor anecdotal or even novelistic masterpiece - incidentally illustrating the overlap of a medical case with short fiction - I have translated it in toto.

Then Dr. Martin Luther said "that there was a devout man, a Werkheiliger, who heard a monk preach about a saint who had stood for three years in one place on a step [of a ladder or stair]. Then he had stood another three years on another and higher step, without in that period eating or drinking anything. As a result maggots had come out of his feet. But as soon as these worms had fallen to the ground, they had turned to pearls and precious stones. And the monk concluded his sermon saying: 'You also must let everything become bloody sour for you if you want to win heaven!' ['Also musst ihrs euch auch lassen blutsaur werden, so ihr wollet selig werden!']

"When the melancholic heard this, he resolved (to put it decorously) not to let water. No one could persuade him to urinate; and he continued like that for several days. Then someone came to him saying that he was doing right in castigating his body and that he should certainly stay with his resolve (to serve God and to make himself suffer), for one entered into heaven through many crosses and tribulations. The same person also pretended that he too had taken a vow not to urinate, but that since he had prided himself on this pledge and had thought to gain heaven by it, he had sinned more than if he had urinated; indeed, he had almost become a murderer of his own body. 'Thus all the world will say similarly of you, that you do so out of pride. Therefore give up your resolve and let nature have its course.' In this way he persuaded the melancholic to urinate. ${ }^{24}$

This case, or we may more appropriately call it an exemplum, illustrates some concerns central to Luther's thought about justification, spiritual temptation (Anfechtung), and melancholy (which he usually calls, using a medieval adage, "the Devil's bath," balneum diaboli), a nexus deserving more thorough exploration than it can receive in the present context.

Luther's presentation of the story is different in two ways from the version that entered the collections of medical commonplaces. Perhaps because of the authority of Galen, who merely listed instances of melancholic behavior, such as claiming to have a body of fragile material, playing the cock, or claiming to support the world on one's shoulders, medieval and Renaissance compendia usually give no history of such patients. Huarte's case of a noble lord's page who fell into the delusion that he was a sovereign 
lord himself is rather unusual, for presumably his kind of madness is related to his station in life. ${ }^{25}$ The connection between the delusion and the patient's kind of life and habits (genus vitae et consuetudo) is not expressed systematically until the early seventeenth century in a Wittenberg dissertation on melancholy, and then the idea is somewhat simplistic: "The theologian claims to speak with angels and to be Christ; ... the chemist disclaims on the making of gold; the miser, however rich, weeps about lacking everything; the astronomer says he is a prophet, the courtier a king."'26 While in the usual version of the voluntary retentive's case his previous history is not explained, Luther gives an etiology: he describes the man as a "iustitiarius" before the onset of his disease, i.e. someone attempting to justify himself by works rather than by faith. For Luther it is appropriate that such a iustitiarius should fall into melancholy (a version of the medieval monks' disease acedia) upon hearing a monk praising a man for castigating himself. The terms in which Luther has the monk urge the congregation to works of penitence are loaded: "Also musst ihrs euch auch lassen blutsaur werden ..." (Thus you must let everything become bloody sour for you too). "Sour" is often Luther's derogatory epithet for the looks or life style of the iustitiarii, whether of Romish or Enthusiast (i.e. Anabaptist) persuasion.

The second way in which Luther's exemplum differs from the versions typically found in medical handbooks of the period is in the kind of cure proposed. We saw that the abnormal behavior in the second case, of the man imitating a cock, was remedied by ingenious persuasion through human contact or company, and that the final sentence Et illa societate illum persuasit could just as well have applied to the first patient (who thought himself dead). In Renaissance terms, this man was not suffering simply from acedia, since his refusal to eat was not a means of mortifying himself: ${ }^{27}$ he thought he was already dead. Thus Luther's version belongs to the cases usually taken to exemplify laesa imaginatio, an injured or harmed imagination, although some medical writers record "cures" significantly more ingenious than Luther's: in Sennert's chapter "De viribus imaginationis," the starving melancholic is joined by someone pretending to be dead yet hungry and by that example is persuaded that corpses also should eat. ${ }^{28}$ As we have seen, in Luther the appeal is more physical and social, to the infectious pleasure commonly experienced by human beings in eating: someone simply wines and dines in the patient's view thus stimulating his fellow creature's appetite. While in these brief stories the evidence for such judgements is scanty, it may be said that in modern terms Luther's "melancholic" comes closer to being cured.

Clearly human company is the essential element in the cure of the melancholic iustitiarius also. Indeed, although the German version translated above omits any "moral," the Latin text draws it in such a way that it 


\section{6 / Renaissance and Reformation}

functions like a refrain: "Et ita illum persuasit societate”' (And thus he persuaded him by company). Just as in the cure of the birdman "company" meant that friend imitated the patient's behavior, so in the case of the retentive iustitiarius it means claiming to have had an experience similar to his. Thus at the outset of therapy, there is an attempt to overcome the psychotic's isolation by demonstratively negating the border between "normalcy" and "insanity".

\section{Cervantes: In the Interaction of Three Traditions}

The most powerful fictional elaboration of the tensions between ridicule, compassionate reintegration (which I see best exemplified in Luther), and the Erasmian stance towards psychotic delusion is Cervantes' Don Quixote, a novel that broadens the issue from a question of the patient's characteristically Erasmian ways of evaluating abnormal states of mind and even suggesting their benefit for society. Uncertainty about the value of the ingenious psychotic's state of mind - is his perception comparable, even preferable to that of the many? - casts a shadow of ambiguity over the intended cure of the ingenioso hidalgo Don Quixote. It is impossible to review here the specific arguments about Don Quixote's humoral condition and cure that have been brought forth since Iriarte's concerted attempt to bring medical history to bear on the novel. ${ }^{29}$ In any case, the disagreements about Don Quixote's condition in terms of humoral physiology (whether he is best explained as an ingenious melancholic $[\mathrm{H}$. Weinrich] or as a colérico with enthusiasm turning melancholic [O. $\mathrm{H}$. Green]) are relatively unimportant in the present context, for ultimately, according to general Renaissance physiological theory, even cholera adusta produces what is also considered a version of melancholy.

Much of the plot is motivated by notions of curing, and the motives of the curers (priest and barber in part I and Sansón Carrasco in part II) are pure at least at the beginning: selected representatives of La Manchan society set out in order to find their fellow villager and to bring him home. Although Cervantes' irony, as complex and subtle as Erasmus's, invariably tempers the moral significance of action, the fundamental strain of compassion and human sympathy evident in these motives of cure comes to the surface in other places in the novel: in Maritornes's offering Sancho a glass of wine after he has been tossed in a blanket $(I, 17)$; in Don Quixote's counsel to Sancho, about to set out to govern his island, to err in favor of mercy, not rigor (II,42); in scattered remarks in various places criticizing those laughing at Don Quixote (without necessarily defending Don Quixote - as e.g. Cide Hamete's comments on the Duke and the Duchess in II,70). To be sure, some of the action (like the comportment of the Duke and Duchess) only shows people's interest in and enjoyment of the madman's genius and thus is equivalent to the noble lord's dubious enjoyment of his schizo- 
phrenic page's wisdom in Huarte's exemplum or the Duke's interest in conversing with Jaques in his fits (in As You Like It). But most of the time it is the ostensible motive of curing Don Quixote that turns much of the novel into a series of masquerades in which the would-be curers enter into the fiction of the patient. Before Sansón Carrasco as the Knight of the White Moon takes on Don Quixote in the final and humiliating bout, he has him agree to return to La Mancha for a year if he should lose. When Don Antonio Moreno after the fight accuses him of having foolishly robbed the world of the benefit of Don Quixote's eccentricities, Sanson Carrasco defends himself, saying "I myself felt particular sympathy for his sad case, and as I believed his recovery to depend upon his remaining quietly at home, I earnestly endeavored to accomplish that end." 30

As we have seen with several cases already, a certain kind of therapy was indicated for patients with fixed delusions, and this therapy was based on a few theoretical assumptions shared by most medical writers. In his section "Of the Force of the Imagination" (pt. 1, sec. 2, memb. 3, subs. 2) and throughout his Anatomy of Melancholy, Robert Burton accurately records a Renaissance trend to assign the causes of melancholy to the imagination. He agrees with Nicholas Piso and other medical authorities in saying that the fountain of distempers is laesa imaginatio ${ }^{31}$ (wounded or injured imagination) and draws upon Thomas Feyens (Fienus), who in an eminently interesting book called De viribus imaginationis held that melancholic humors result from prava imaginatio (distorted imagination). Hence, said Feyens, they cannot be expelled from the body except by inducing other and contrary images in the imagination. In the resulting therapy, the healers become stage managers and actors who act within the fiction of the patient, even expanding it. Thus one finds scores of reports like those of people who believed they contained frogs or snakes and were cured by a physician who pretended to extract the animals from their innards, or of patients who thought that antlers were growing on their heads and were healed by a clever physician's simulated operation. ${ }^{32}$

Surely no one familiar with Renaissance medical notions about curing laesa imaginatio will miss the attempts at manipulating Don Quixote in the interest of a presumed cure, but the fictions resorted to are so elaborate that Cervantes may have been satirizing exactly this medical theory. The would-be therapists devote themselves to their masquerade with so much enthusiasm that in their fascination for the means they lose sight of the end; as a result they seem at times as deluded as Don Quixote himself. Thus Sansón Carrasco engages Don Quixote in the final bout ostensibly in order to get him home for a year, but Oscar Mandel, who has sifted through the novel's characters to determine which come closest to being reliable and reasonable agents and spokesmen for the author, is undoubtedly correct when he calls Sansón a "doubtful referent." ${ }^{33}$ Not only is he too bungling in 
his attempts to get Don Quixote home, but even Sansón's motives are questionable: while after the final joust Sansón claims that he has had Don Quixote's interests and specifically his cure in mind (II ch. 65), the reader remembers that Sansón Carrasco had at one point affirmed the opposite. After being defeated by Don Quixote, he had said to his own "squire" "It is not my wish to make him recover his wits that will drive me to hunt him now, but my lust for revenge" (II, ch. 15). That many a reader has agreed with Don Antonio's reprimand of Sansón Carrasco is an index of how deeply the Erasmian spirit pervades the novel:

May God forgive you for the wrong you have done in robbing the world of the most diverting madman who was ever seen. Is it not plain, sir, that his cure can never benefit mankind half as much as the pleasure he affords by his eccentricities? But I feel sure, sir, that all your art will not cure such deep-rooted madness; were it not uncharitable, I would express the hope that he may never recover, for by his cure we would lose not only the knight's company, but also the drollery of his squire, Sancho Panza, which is enough to transform melancholy itself into mirth. (II, ch. 65; Starkie trans., p. 995)

Though we know that Sansón Carrasco succeeds in getting Don Quixote back to his village, at the entrance to which Don Quixote experiences what psychiatrists now call "ideas of reference" (he interprets a hare fleeing toward him as a malum signum), and that Don Quixote finally regains sanity on his deathbed, Cervantes does not give anyone unambiguous credit for the "cure" - neither Sansón Carrasco nor any other would-be therapist from La Mancha, including the doctor. It may well be that he wishes to reserve for God the distinction of being the ultimate physician.

While Don Antonio's view is not the last word on the ingenious psychotic, in its moral ambiguity (the opposition of charity versus delight as incapsulated in the expression "diverting madness") it highlights Erasmian tenets and enriches them with the aesthetic pleasures of watching a character so obsessed with books that he takes his imagined world for real. While this genetic view of Cervantes' thought may perhaps simplify his tantalizing creation inordinately (obscuring for instance the point that Don Quixote never hallucinates), it should be noted that some of the seeds of his accomplishment are contained in the kind of topical medical cases we have been considering. The Greek madman who sat in a theater alone for days on end "saw" an imaginative creation, evaluating it emotionally or aesthetically. And just as this Athenian psychotic singled out by Erasmus represents a hyper-cultural phenomenon, so unquestionably "bookish" patients suffering mental illness are quite common in medical discussions in the Renaissance. Renaissance doctors are not averse to drawing upon literary characters and episodes, doing so eclectically of course, without the Freudian and Jungian underpinnings that motivate most modern 
attempts at bridging the gap between life and literature. Thus Lavater reports that the slighted Ajax became so "madde through griefe" that he drew his sword and "set upon herds of swine supposing that he fought with the whole army of the Grecians ..." 34 - an episode that will strike one as potentially Quixotic.

There is no question that Don Antonio's reaction is plotted in the tension field between delight and charity, for he says so ("were it not uncharitable," etc.). The same tension animates what may be the most moving episode of this kind in the novel - Sancho's pleading words to Don Quixote, who is on his deathbed and resigned to die: "Up with you this instant, out of your bed, and let us put on shepherd's clothing and off with us to the fields as we were resolved a while back. Who knows but we may find Lady Dulcinea behind a hedge, disenchanted and as fresh as a daisy" (II, 74; Starkie trans. p. 1047). If we assume that Sancho at this point in the novel cannot hope any more to find the world of romance (pastoral or other) in his own world, his suggestion is comparable to the Lutheran healer's compassionate act: he will keep Don Quixote company to prolong his life. But the categories I have been distinguishing are only the roughest guides in a complex situation like this one, veiled in subtle irony: for Sancho's proposal, though charitable, also affirms his pleasure in their unusual companionship. Therefore it is more to the point to say that Cervantes here manages to transform the (Erasmian) pleasure taken in Don Quixote's madness into sympathy and brotherhood. In Sancho's spontaneous and feeling reaction, Cervantes transcends the categories' separateness.

The two elements which I find in nuce in Luther's thinking about cases of "melancholics," namely the consideration of the psychotic's past and the role of societas in re-integrating such a person into the community, are highlighted with an almost uncanny perspicuity (and without the irony veiling the compassion in Don Quixote) in a novella by Cervantes that has long been considered the most puzzling but also fascinating of his short works. ${ }^{35}$ Working from the kind of topical medical exempla we have reviewed in this paper and of course thinking in the context of the humoral physiology reigning in his period, Cervantes' imaginative genius highlights problems of communal integration not only in therapy but also after some "cure" has been accomplished, thus going far beyond the theoretical interests of medical academicians of his time.

"El Licenciado Vidriera," one of Cervantes' Novelas ejemplares, tells the story of a young man with a good memory (good memory in humoral physiology distinguishes the melancholic) who sees the world, returns to Salamanca to take his law degree, but because of a supposed love potion secretly administered to him falls grievously ill. He recovers physically but becomes "mad" or "melancholic," or as we would say, psychotic: 
The poor wretch imagined that he was all made of glass, and under this delusion, when someone came up to him, he would scream out in the most frightening manner, and using the most convincing arguments would beg them not to come near him, or they would break him. ${ }^{36}$

Along with his delusion the licenciado acquires stunning wisdom: he baffles the professors of medicine and philosophy by answering the most difficult questions put to him, and Cervantes spends the larger part of the novella giving examples of his ingenious perceptions and sayings. The story thus presents a version of the melancholic of genius in the tradition of pseudoAristotle's problem XXX,1, a tradition that has been described by Saxl, Panofsky, and others. ${ }^{37}$

Modern scholars are undoubtedly correct if they see the story as a conflation of a psychiatric case in the tradition of Galen (of a man believing he is made of some brittle substance) with Huarte's case (mentioned above) of the page with the delusion of being sovereign of a realm. ${ }^{38}$ But Huarte's story here reveals an affiliation that Cervantes' "Licenciado Vidriera" does not have: the page enjoys being treated like a lord (he is somewhat like Shakespeare's Sly in the induction scene to The Taming of the Shrew). As we have seen, the cure, which is not explained, returns the page to a disappointing reality: "For while I rested in my folly, I led my life in the deepest discourses of the world, and imagined my self so great a lord as there raigned no king on the earth, who was not my vassal, and were this iest or lie, what imported that, whilest I conceived thereof so great a contentment, as if it had bene true?' (p. 44). Thus Huarte's case is ultimately a version of Athenaeus' case of Thrasyllos, the imagined owner of all the ships in the harbor of Piraeus, who later lamented his cure. The case of Cervantes' licenciado is not of the Athaenean/Erasmian type. Although this wise madman's pronouncements may be said to appeal to an interest similar to that of a string of Erasmian apothegmata, ${ }^{40}$ the licenciado does not enjoy his ability to coin pithy sayings, many of which are righteous, caustic, some even uncharitable. Nor does he derive any pleasure from his conviction that his body is made of glass.

As Harald Weinrich says, the motif of the man of glass presupposes the traditional conception of the body as vessel of the soul. ${ }^{41}$ Indeed, some of the gifts traditionally attributed to melancholics in the pseudo-Aristotelian and Ficinean tradition, for instance the gift of divination, were commonly explained as the result of the higher penetrability of their bodies to the subtlest spiritus and astral influences. But this learned reading by no means precludes the psychiatric (or perhaps in this case we should say Laingian) interpretation, in which the schizophrenic's particular delusion is seen as the result of a trauma and of fear of more wounds. Not only has Cervantes' licenciado been hurt by a person who wanted to be very close to him (i.e. 
wanted him), but the novelist makes it clear that the man of glass is especially vulnerable to human contact. He tells us of attempts to cure him that are as well-intentioned as the ones recorded in Luther's exempla but lack the fuller understanding of the psychotic person that characterized those:

\begin{abstract}
In order to relieve him of his strange delusion, many people, taking no notice of his shouts and pleas, went up to him and embraced him, telling him to look and he would see that in fact he was not getting broken. But all that happened as a result of this was that the poor wretch would throw himself on the ground shouting for all he was worth, and would then fall into a faint, from which he did not recover for several hours; and when he did come to he would start begging people not to come near him again. ${ }^{42}$
\end{abstract}

Thus unlike Athenaeus' Thrasyllos and Huarte's page, this "paranoid schizophrenic" as he has been called, ${ }^{43}$ suffers pain in his psychotic condition in spite of his stupendous gifts, in fact so much pain that most readers, past and present, expect a cure to turn the novella into a "success story." The cure, in contrast to that of Huarte's exemplum, is brought about not by a physician "with a mind to receive some good reward" (p. 43), i.e., for financial gain, but by a monk of the Hieronymite order "out of charity" ( $p$. 145).

Since Cervantes gets the licenciado's cure over with in a couple of sentences, it might be thought that he was not interested in the subject, but nothing could be more incorrect. His introduction of the healer's charity is in some way equivalent to Luther's emphasis on notions of Gemeinschaft and Gesellschaft (societas), which are animated by it, and may (as Gwynne Edwards suggested) have had special significance for Cervantes, who was delivered from North African Moslem slavery by the patient and charitable efforts of certain mendicant monks; even more so it may reverberate with Cervantes' own charity, the impulsiveness of which defied worldly prudence so much that he was once clapped into jail for aiding a mortally wounded victim of a street fight. ${ }^{44}$

Of course Cervantes' story of the man of glass does not end happily with this cure. After the patient has returned to sanity, Cervantes adds another reversal to the plot: in spite of the licenciado's pleas, the townspeople of Salamanca do not allow him to return to normalcy and practice law. They are unwilling or unable to accept his cure. The stigma of his past condition is so strong that he has to leave town, profession, and country.

In source studies one should not emphasize similarity but grant it, and then interpret the differences. From my perspective it is not so important to agree or disagree with Saturnino Rivera Manescáu's contention that at Valladolid Cervantes heard from the physician Antonio Ponce Santacruz the case of a Parisian "man of glass" not reported in print until 1622; to 
accept the possibility or even likelihood that Cervantes knew the case would not, as Walter Starkie supposes, "diminish his genius,"45 for the therapy Santacruz reports is too different: the doctor has the patient lie on a bed of straw (Cervantes' licenciado also likes to protect his seemingly fragile body with straw) and, setting a fire, leaves:

This done, he decamped rapidly, shutting the door and leaving the madman to his own devices. The latter, finding himself encircled by flames, jumped up in terror and beat upon the door with all his strength, but without breaking or injuring himself, crying out that he no longer believed he was made of glass. Thus the terror of being consumed by fire was so great that it caused his mania to disappear. ${ }^{46}$

This therapy is harsh, and we may wonder how the licenciado might have reacted to it: he might have fallen into a faint (as Cervantes reports him to have reacted to the equally harsh though perhaps less ingenious treatment of the Salamancans) and might have incurred the same fate as the patient who against his will was carried through a door he thought was too narrow for his body.

\section{Conclusion}

As we saw, Luther shows none of the dehumanizing amusement that often animates even learned physicians when they report certain kinds of cases. In his exempla the imagination is used, at most, to gain a patient's confidence, but the 'cure' is brought about not by trickery but by friendly persuasion, by appeal to common humanity, by company. There is taunting amusement in Cervantes' "El Licenciado Vidriera," but he puts this amusement in perspective by demonstrating that it is destructive. Certainly the riffraff among the Salamancans prefers an insane to a sane licenciate - perhaps this is Cervantes' later comment on Erasmian views of madness. The entire story is informed by a strong sense of sympathy for a patient who becomes stigmatized by society.

While we know that the glass graduate's cure was motivated by charity, we cannot be sure about motivation in Don Quixote. The simplicity and efficiency of the Hieronymite monk contrasts with the elaborate and bungling attempts of somelike like Sansón Carrasco. The charity of the former (affirmed by the author) contrasts with the motives of the latter, which are often tainted or at least questionable. If there is no unambiguous sign of a therapy in La Mancha, this may be because there is no Hieronymite monk movido de caridad and no friend unambiguously curing in the spirit of Luther's Gemeinschaft. Sancho's desperate attempt to prolong Don Quixote's life is spontaneous and moving, but it is part of Cervantes' irony to present Sancho as ill-equipped for the therapeutic task. Another element of irony is that at the time of Sancho's compassionate proposal Don Quixote 
has just come to his senses through the help of no physician except perhaps, as the narrator veiledly hints, the Divine.

It would seem that Luther and Cervantes represent the best of a long psychiatric tradition. So does Samuel Johnson in a later century when he has Rasselas and his sister meet an astronomer who believes that he regulates the seasons, another case that goes back to Donati, and through him to Avicenna. ${ }^{47}$ The recluse gets relief from his terrifying spectres and is gradually weaned away from his imagined absorbing task through freely proffered male and female friendship.

Is William Wharton's best-selling Birdy (to mention only one modern example of a psychiatric novel) evidence that in our times the give and take between imaginative fiction and psychiatry has been reversed? This engaging work shows how the inmate of a psychiatric ward, whom we meet at the outset perched in bird fashion on his toilet seat, is very slowly wakened from his catatonic state by his former playmate's gently recalling childhood feats in which they shared: Lutheran societas and Cervantesque consideration of the patient's past, both of course now informed by a postFreudian understanding of childhood experience. But to name Freud, a man steeped in the imaginative literature of the past (and from his youth a reader of Cervantes ${ }^{48}$ ), suffices to prevent an easy answer to my question. Further, while much of the focus in Birdy is indeed psychiatric, the professional army psychiatrist in the novel is perceived as the patient's antagonist and thus remains unable to help him. An element of the novel's imaginative core aligns it with the movement somewhat unfortunately called "anti-psychiatry," a movement broader than a fad, with eminently respectable antecedents as we have seen. One may hope that the antagonistic stance is only a passing phase - certainly antagonism to medicine (or psychiatry) has not motivated the best writers old or new. The kind of cases we have considered, so instructive because they are in a sense extreme and represent the cas limite of human consciousness, call upon an interpretive ability that is decidedly similar in psychiatrist and imaginative artist, for R. D. Laing is no doubt correct in saying that the kernel of the schizophrenic's experience of himself remains incomprehensible (p. 39).

\section{University of California-Davis}

\section{Notes}

1 Advancement of Human Learning, Bk. 2, in Bacon, Works, ed. James Spedding et al. (London: Longmans, 1859), III, 373. In a strict sense "schizophrenia" was of course not defined until early in this century (by Eugen Bleuler), see Silvano Arieti, Interpretation of Schizophrenia, 2nd. ed. (New York: Basic Books, 1974), ch. 2. In the Renaissance all such psychoses as intended in my title were included under melancholia, an extensive term which has only recently been narrowed to a particular psychotic condition.

2 See Critical Psychiatry: The Politics of Mental Health, ed. David Ingleby (New York: Random House, 1980), p. 8 and passim. 


\section{4 / Renaissance and Reformation}

3 The Divided Self (London: Travistock, 1960), p. 38.

4 The Divided Self, p. 39.

5 De locis affectis, bk. 3, ch. 10 in Galen, Opera ed. C. G. Kühn (Leipzig, 1821-33), VIII, 190: "... siquidem alius testaceum se factum putavit, atque idcirco occurrantibus cedebat, ne confringeretur, alter gallos cantare conspiciens, ut hi alarum ante cantum, sic ille brachiorum plausu latera quatiens, animantium sonum imitatus est."

6 Tommaso Garzoni, $L$ 'hospidale de' pazzi incurabili (Venice, 1601), p. 101: “E'assai ridiculoso ancora quello de collui, che, parendoli esser devenuto un vetro, ando a Murano, per gettarsi dentro un fornace e farsi fare in foggia d'un inghistara."

7 André du Laurens, A Discourse of the Preservation of Sight: Of Melancholike Diseases, trans. $\mathbf{R}$. Surphlet (London, 1599), p. 103. The French ed. is of Paris, 1597.

8 Donati, De medica historia mirabili (Mantua, 1586), fol. 34fi; Burton, Anatomy, pt. 1, sec. 3, mem. 1, subs. 3 (Shilleto ed., vol. I, 460), Walkington, The Opticke Glasse of Humours (London, 1607), fol. 72; Beyerlinck, Magnum theatrum vitae humanae (Lyons, 1678), V. 398C.

9 Ludwig Lavater, Of Ghostes and Spirites Walking by Night, trans. R. H. (London 1572), p. 10.

10 Marcello Donati,De medica historia mirabili, fol. 34; Ercole Sassonia, De melancholia (Venice, 1620), p. 31; Thomas Feyens [Fienus], De viribus imaginationis, 3rd ed. (London, 1657), p. 160 and pp. 167-68.

11 Erasmus, Praise of Folly, trans. Clarence H. Miller (New Haven and London: Yale University Press, 1979), p. 58.

12 Praise of Folly, trans. C. H. Miller, p. 58.

13 Praise of Folly, trans. Hoyt H. Hudson (Princeton: 1941), p. 149 and Praise of Folly, trans. C. H. Miller, p. 58, note 5. Miller suggests that Erasmus may have intended to show Folly deliberately twisting Cicero's words.

14 Praise of Folly, trans. C. H. Miller, pp. 58-59.

15 Aristoteles, De mirabilibus auscultationibus 832 b 17, in Arist., Minor Works, trans. W. S. Hett (Loeb Classical Library, 1936), p. 251.

16 Lavater, op. cit., p. 11.

17 Athenaeus, Dipnosophistae, trans. Charles B. Gulick (Cambridge, Mass. and London: Loeb Classical Library, 1933), V, 521.

18 Aristotle, Problems, trans. W. S. Hett (Loeb Classical Library, 1937), p. 155.

19 The Examination of Mens Wits [Examen de ingenios], trans. R. C. (London, 1594), p. 43.

20 Juan Huarte de San Juan, Examen de ingenios, ed. Rodrigo Sanz (Madrid: La Rafa, 1930), p. 129.

21 Madness and Civilization: A History of Insanity in the Age of Reason, trans. Richard Howard (New York: Random House, 1965), p. 95. The reference is to Paul Zachias, Quaestiones medicolegales (Avignon, 1660-61).

22 Luther, Tischreden (Weimar: Böhlau, 1912-19), III, 52: “Ich mus mit dir trincken und kans nicht lassen, wan ich hundert mal todt were."

23 Luther, Tischreden, vol. III, 52.

24 Luther, Tischreden, vol. III, pp. 52-53:

Darnach sagete D. Martin Luther, "dass ein gut fromm Mensch wăre gewesen, ein Werkheiliger; der hatte von einem Mönch hören predigen, dass ein Heiliger gewesen wăre, der hătte auf einer Stufen an einer Stätte drei Jahr uber gestanden. Darnach auf einer andern und höhern Stufen wäre er noch einmal drei Jahre gestanden, und hătte diese Zeit uber gar nichts gessen noch getrunken. Drüm waren aus seinen Füssen Maden gewachsen. Aber alsbalde solche Maden auf die Erde gefallen, so wăren daraus lauter Perlen und köstliche edele Gesteine worden. Und hatte der Mönch die Predigt mit diesem Exempel beschlossen und gesagt: 'Also musst ihrs euch auch lassen blutsaur werden, so ihr wollet selig werden!' 
Da dieses ein Melancholicus gehört, hatte er ihm fürgesetzet, er wollte sein Wasser (mit Züchten zu reden) nicht von sich lassen. Es hatte ihn auch kein Mensch darzu bereden können, dass er hätte wollen pinkeln. Und solches hatte er etzliche Tage gethan. Darnach kömmt einer zu ihm und uberredet ihn, "dass er daran recht thăte, dass er seinen Leib casteiete, und sollte ja bei diesem Fürsatz und Gelübden (Gott zu dienen, und ihme selber wehe zu thun, und den alten Adam zu tödten und zu creuzigen), verharren und bleiben, denn man müsste durch viel Creuz und Trübsal eingehen ins Himmelreich. Item derselbige hatte sich gestellet, dass er auch ein solch Gelübde hätte gethan und ihm fürgenommen, nicht zu pinkeln, aber da er auf diesem Gelübde stolziret hătte und vermeinet, dardurch den Himmel zu verdienen, hätte er mehr gesündiget, denn wenn er hätte gepinkelt. Auch wăre er schier ein Mörder an seinem eigenen Leibe worden. Darüm so wird alle Welt dergleichen von dir sagen, dass du es aus Hoffart thust; so stehe nun von deinem Fürsatz ab und lass der Natur ihren Gang.' Also hatte er den Melancholicum uberredet, dass er wieder gepinkelt hatte."

25 Juan Huarte de San Juan, Examen de ingenious, ed. R. Sanz (Madrid: La Rafa, 1930), pp. 119-20.

26 Tobias Tandler (Praeses), De melancholia eiusque speciebus (Wittenberg, [1608], no. LXI: "Sic et vitae genus et consuetudo phantasmata variat. Theologus enim se cum angelis loqui, se Christum profitetur: Juris studiosus acta fori declamat; Chymicus auri confectionem; avarus etsi opulentissimus, omnium rerum inopiam deflet: Astronomus, se prophetam; aulicus se regem vendicat."

27 On acedia, see Mark D. Altschule, "Acedia: Its Evolution from Deadly Sin to Psychiatric Syndrome," British Journal of Psychiatry, 111 (1965), 117-19; Noel L. Brann, "Is Acedia Melancholy? A Re-examination of this Question in the Light of Fra Battista da Crema's Della cognitione et vittoria di se stesso (1531),"Journal for the History of Medicine and Allied Sciences, 34 (1979), 80-99; and Siegfried Wenzel, The Sin of Sloth: Acedia in Medieval Thought and Literature (Chapel Hill, N.C.: University of North Carolina Press, 1967). Cf. also Susan Snyder, "The Left Hand of God: Despair in Medieval and Renaissance Tradition," Studies in the Renaissance, 12 (1965), 18-59.

28 Daniel Sennert, De chymicorum cum Galenicis consensu ac dissensu liber I, ch. 14 (Wittenberg, 1619), p. 403: "Alius quoque qui se mortuum esse imaginabatur, et cibum propterea aspernabatur, socii comitate, qui cum eo se in sepultero mortuum esse asserebat, et quod ipse mortuus cibum caperet, ad cibum capiendum persuasus fuit; ut refert Holer. lib. 1. de morb. inter. cap. 15." The reference is to the French doctor Iacobus Hollerius, De morbis internis, bk. I, ch. 16 (Lyons, 1588), p. 63, where the story is told as Sennert reports it.

29 M. de Iriarte, S. J., El doctor Huarte de San Juan y su Examen de ingenios (Madrid: Consejo Superior de Investigaciones Cientificas, 1948 [first ed. Münster, 1938]; Harald Weinrich, Das Ingenium Don Quijotes (Münster: Aschendorf, 1956); Otis H. Green, "El Ingenioso Hidalgo," Hispanic Review, 25 (1957), 175-193.

30 Don Quijote, trans. Walter Starkie (New York: Signet), p. 994. This is pt. 2, ch. 65, ed. Martin de Riquer (Barcelona: Editorial Juventud, 1958), p. 1014: “ ... y entre los que más se la han tenido he sido yo; y creyendo que está su salud en su reposo, y en que esté en su tierra y en su casa, di traza para hacerle estar en ella."

31 Anatomy of Melancholy, pt. 1, sec. 2, memb. 3, subs. 1 (Shilleto ed., vol. 1, 290).

32 For these and other topical cures, see Marcello Donati, De medica historia mirabili (Mantua, 1586), fol. 34 and Ercole Sassonia, De melancholia (Venice, 1620), p. 31, who spells out the principle of deception.

33 Oscar Mandel, "The Function of the Norm in Don Quijote, MP, 55 (1957-58), 160.

34 Lavater, Of Ghostes and Spirites, p. 13.

35 See Gwynne Edwards, “Cervantes's "El Licenciado Vidriera': Meaning and Structure," MLR, 68 (1973), 589. Also Dana B. Drake, Cervantes' Novelas Ejemplares: A Selective, Annotated Bibliography (2nd ed.; New York \& London: Garland, 1981), pp. 135-54. The most penetrating analysis of the Licenciado as a paradoxical cynic philosopher censured by Erasmian humanitas is by Alban K. Forcione, Cervantes and the Humanist Vision: A Study of Four Exemplary Novels (Princeton University Press, 1982), pp. 260-316. 


\section{6 / Renaissance and Reformation}

36 Exemplary Novels, trans. C. A. Jones (Baltimore: Penguin, 1972), p. 128.

37 The pioneering studies of Saxl and Panofsky are summarized and expanded in Raymond Klibansky, Erwin Panofsky, and Fritz Saxl, Saturn and Melancholy (London: Nelson, 1964). See also Rudolf Wittkower, Born under Saturn (London: Weidenfels and Nicolson, 1963), ch. 5: Genius, Madness, and Melancholy"; Lawrence Babb, The Elizabethan Malady (East Lansing: Michigan State College Press, 1951); and Bridget Gellert Lyons, Voices of Melancholy (London: Routledge \& Kegan Paul, 1971).

38 In the Renaissance this case is a locus communis, and (as Weinrich points out) Cervantes could have found it in Jason Pratensis, De cerebri morbis (Basel, 1549), ch. 18, p. 270 or in Ludovicus Caelius Rhodiginus (=Ludovico Ricchieri), Lect. ant. 17,2; p. 625. See Harald Weinrich, Das Ingenium Don Quijotes (Forschungen zur Romanischen Philologie, Heft 1), Münster:Aschendorf, 1956, pp. 51-52; also Otis H. Green, "El Licenciado vidriera: Its Relation to the Viaje del Parnaso and the Examen de ingenios of Huarte" in The Literary Mind of Medieval and Renaissance Spain, ed. John E. Keller (The University Press of Kentucky, 1970), pp. 190-92. In addition to the works cited by Weinrich, the following ones also contain the case of a person imagining to have a brittle body: Bernard Gordonius, Opus lilium medicinae: De morborum curatione, bk. 2, ch. 19 (Lyons, 1574), p. 211 says: "Alii videntur, quod sint vasa vitrea vel argillosa, et timent quod si tangerentur, frangerentur"; Marcello Donati, De medica historia mirabili (Mantua, 1586), fol. 35 and 36fi, mentions people with bodies of clay and legs of glass.

39 Huarte, The Examination of Mens Wits, trans. R. C. (London, 1594), p. 43.

40 The authoritative study of Erasmian influence on Spain in general and Cervantes in particular is Marcel Bataillon, Erasmo y España: estudios sobre la historia espiritual del siglo xvi (2nd ed., Mexico: Fondo de Cultura Económica, 1966). But "influence" rarely means wholesale acceptance of a paradigm. In spite of the narrowness of my focus, my spotlight may still help clarify the larger issue of Cervantes' relationship to Erasmian thought.

41 Weinrich, Das Ingenium Don Quijotes, p. 51.

42 Exemplary Novels, trans. C. A. Jones (Penguin ed.), pp. 128-29.

43 A. Vallejo Nájera, Literatura y psiquiatria (Barcelona: Edit. Barcelona, 1950), pp. 43-44, 49.

44 Most biographies of Cervantes mention the role of the Order of the Most Holy Trinity for the Redemption of Captives (OSST) in freeing Cervantes from bondage, see e.g. William Byron, Cervantes: A Biography (Garden City: Doubleday, 1978), pp. 242-46. James Fitzmaurice-Kelly mentions both biographical events (Miguel de Cervantes Saavedra: Reseña documentada de su vida [Buenos Aires: Editorial Bajel, 1944], chs. iv and ix); Edwards relates them to Vidriera, $M L R, 68$ (1973), 566.

45 See Starkie's otherwise informative Foreword (p. $x x)$ to his transl. Cervantes, The Deceitful Marriage and Other Exemplary Novels (New York: Signet, 1963). G. Hainsworth also is concerned only with similarity; see "La source du 'Licenciado Vidriera'," Bulletin Hispanique, 32 (1930), 70-72. For S. Rivera Manesćau's argument, see his “El Modelo del Licenciado Vidriera” in Fiesta del Libro: IV Centenario de Miguel de Cervantes (Universidad de Valladolid, 1947), 111.

46 Walter Starkie's paraphrase in his Foreword to Cervantes, The Deceitful Marriage and Other Exemplary Novels, p. xx.

47 Donati, De medicina historia mirabili, fol. 36f: “Avic. itaque 4. Naturalium 6. tantum imaginationi tribuit, et pluvias, et tonitrua, terremotusque ad libitum excitare, et aegritudines inducere, ac sanare poterit, ait Montanus in com. in 2 fen. 1 Avic. se hominem quendam vidisse, qui ex sola forti imaginatione quoties volebat, in facto circulo plusquam centum serpentes convocabat."

48 See S. B. Vranich, "Sigmund Freud and 'The Case History of Berganza': Freud's Psychoanalytic Beginnings," Psychoanalytic Review, 63 (1976), 73-82. 